\title{
Structure of $\alpha_{\mathrm{s} 1}$-Casein at an Oil/Water Interface: An Analytical Approach Using Immunochemical Methods
}

\author{
Akio Ametani, Makoto Shimizu, Shuichi Kaminogawa \\ and Kunio YamaUCHI \\ Department of Agricultural Chemistry, The University of Tokyo, \\ Bunkyo-ku, Tokyo 113, Japan \\ Received November 15, 1988
}

\begin{abstract}
The structure of $\alpha_{\mathrm{s} 1}$-casein at an emulsified oil/water interface was studied by immunochemical method using BALB $/ c$ mouse anti- $\alpha_{\mathrm{s} 1}$-casein antibody. By incubating the antiserum with an $\boldsymbol{\alpha}_{\mathrm{s} 1}$-caseinstabilized emulsion, all of the specific antibodies in the serum were absorbed by the emulsion, suggesting that $\alpha_{\mathrm{s} 1}$-casein was adsorbed to the oil surface, all of its antigenic determinants being exposed to the aqueous phase. Since the antigenic determinants of $\alpha_{\mathrm{s} 1}$-casein for BALB/c mice are known to be present in the regions of residues $1 \sim 8,33 \sim 54,105 \sim 119,133 \sim 151$, and $174 \sim 199$, these portions must be, at least partly, exposed to the aqueous phase and accessible to the antibodies.
\end{abstract}

Proteins are generally surface active, and many proteins have good emulsifying properties which are beneficial for manufacturing various emulsified food. ${ }^{1)}$ The emulsifying property is strongly dependent on proteinlipid interactions occurring at an oil/water interface during emulsification. The proteinlipid interaction in emulsion should, therefore, be elucidated for the understanding of protein emulsification. However, the mechanism of protein-lipid interaction at an oil/ water interface is not clearly understood. The molecular structure of proteins on the surface of oil droplets had been little investigated until we reported a schematic representation of an bovine $\alpha_{\mathrm{s} 1}$-casein polypeptide adsorbed to an emulsified oil surface. ${ }^{2)}$ In that paper, by an analytical approach using protease digestion and high-performance liquid chromatography, we proposed a structure of $\alpha_{\mathrm{s} 1}$-casein at an oil/water interface-interaction of $\alpha_{s 1}$-casein with an oil surface through multiple binding sites (nine particular sites of relatively high hydrophobicity) in the polypeptide chain. To confirm this model, however, further experiments using a different analytical approach must be done.

The antibody-antigen reaction is known to be highly specific, and antibodies are believed to be good tools to monitor the antigen molecules in heterogeneous systems. ${ }^{3,4)}$ Since the antigenic determinants of $\alpha_{\mathrm{s} 1}$-casein in mice have already been identified, ${ }^{5,6)}$ we introduced an immunochemical approach for getting specific information of the particular sites of the $\alpha_{\mathrm{s} 1}$-casein molecule on the emulsified oil surface. In this study, the reaction of a polyclonal antiserum against bovine $\alpha_{\mathrm{s} 1}$-casein with $\alpha_{\mathrm{s} 1}{ }^{-}$ casein-coated oil droplets was analyzed, through which the localization of the antigenic determinants of $\alpha_{\mathrm{s} 1}$-casein on the oil droplet surface was discussed.

\section{Materials and Methods}

Preparation of $\alpha_{\mathrm{s} 1}$-casein. $\alpha_{\mathrm{s} 1}$-casein was prepared from fresh skim milk as described previously. ${ }^{2)}$

Preparation of the emulsion. A $1 \% \alpha_{\mathrm{s} 1}$-casein solution $(\mathrm{pH} 7)$ was homogenized with $20 \%$ (w/w) tricaprylin (Sigma Chemical Co.) by using a Polytron PT-20 (Kinematica $\mathrm{GmbH}$ ) at full speed for $8 \mathrm{~min}$ at $30^{\circ} \mathrm{C}$. The emulsion was then diluted with $0.1 \mathrm{M} \mathrm{NH}_{4} \mathrm{OH} / \mathrm{HCOOH}$ buffer (pH 8.5) and centrifuged at $27,000 \times g$ for $10 \mathrm{~min}$ at $20^{\circ} \mathrm{C}$. The aqueous portion was removed by aspiration. The floating cream was diluted with the same buffer, gently mixed, and centrifuged at $12,000 \times g$ for $10 \mathrm{~min}$. A washed cream (oil globule fraction) was obtained by re- 
peating this step twice.

Preparation of the anti- $\alpha_{\mathrm{s} 1}$-casein antiserum. An anti- $\alpha_{51}$ casein antiserum was prepared by injecting BALB $/ c$ mice with $\alpha_{s 1}$-casein as described previously. ${ }^{5)}$ The immunoglobulin fraction was prepared from the antiserum by ammonium sulfate precipitation ( $50 \%$ saturation), followed by dialysis against PBS.

Enzyme-linked immunosorbent assay (ELISA). One hundred microliters of a $0.01 \% \alpha_{s 1}$-casein solution in phosphate buffer saline (PBS) was added to each well of a Petra plastic microtiter plate (Sanko Junyaku Co., Ltd.), and the plate was incubated for $2 \mathrm{hr}$ at room temperature. After removal of the solution, the wells were washed three times with $125 \mu \mathrm{l}$ of PBS containing $0.05 \%$ Tween 20 (PBSTween). Then $100 \mu \mathrm{l}$ of $1 \%$ ovalbumin in PBS was added and the plate incubated for $2 \mathrm{hr}$. After removal of the ovalbumin solution and triplicate washing with PBSTween, $100 \mu$ of an antibody solution (antiserum) appropriately diluted with PBS was added and incubated for $2 \mathrm{hr}$. The anti- $\alpha_{\mathrm{sl}}$-casein antibody bound to each well was measured using alkaline phosphatase(Sigma Chemical Co.)-labelled goat anti-mouse IgG (Cappel) as described previously. ${ }^{3)}$

Antibody-antigen reaction in emulsion. The washed cream $\left(\alpha_{\mathrm{s} 1}\right.$-casein-stabilized emulsion) dispersed in $0.1 \mathrm{~m}$ $\mathrm{NH}_{4} \mathrm{OH} / \mathrm{HCOOH}$ buffer ( $\mathrm{pH} 8.5$ ) was mixed with different amounts of antiserum appropriately diluted with the same buffer. The mixture was incubated at room temperature for $2 \mathrm{hr}$ and then centrifuged at $12,000 \times g$ for $10 \mathrm{~min}$. The aqueous portion was recovered by aspiration and served for antibody measurement by ELISA

Staining of washed oil globules with fluorescent-labelled immunoglobulin. Flourescein isothiocyanate (FITC)labelled goat anti-mouse $\operatorname{IgG}$ (heavy and light chain specific) was purchased from Cappel. Washed cream prepared from the $\alpha_{\mathrm{s} 1}$-casein-stabilized emulsion was mixed with a half volume of an anti- $\alpha_{\mathrm{s} 1}$-casein antibody solution and incubated for $2 \mathrm{hr}$ at room temperature. Ten volumes of $0.1 \mathrm{M} \mathrm{NH} \mathrm{N}_{4} \mathrm{OH} / \mathrm{HCOOH}$ buffer $(\mathrm{pH} 8.5$ ) was added to the mixture and then the aqueous phase was removed by centrifugation. To the cream phase (oil globule fraction) was added FITC-labelled goat anti-mouse IgG. The mixture was incubated at room temperature for $2 \mathrm{hr}$ in the dark, diluted with the buffer, and then centrifuged to remove unbound antibodies in the aqueous phase. The cream phase obtained here was observed by Olympus $\mathrm{BH}$ 2-RFL fluorescence microscope with UV illumination at $365 \mathrm{~nm}$

\section{Results and Discussion}

The surface of the emulsified oil droplets was homogeneously stained by a fluorescence method using an anti- $\alpha_{\mathrm{s} 1}$-casein antibody together with the fluorescence-labelled secondary antibody (Fig. 1), suggesting that the surface was entirely coated with $\alpha_{\mathrm{s} 1}$-casein. This result also demonstrates that antigen determinants of an $\alpha_{\mathrm{s} 1}$-casein molecule are, at least partly, extended to the aqueous phase and accessible to the antibodies.

Non-specific binding or adsorption of the antibodies to the oil droplets was ruled out,

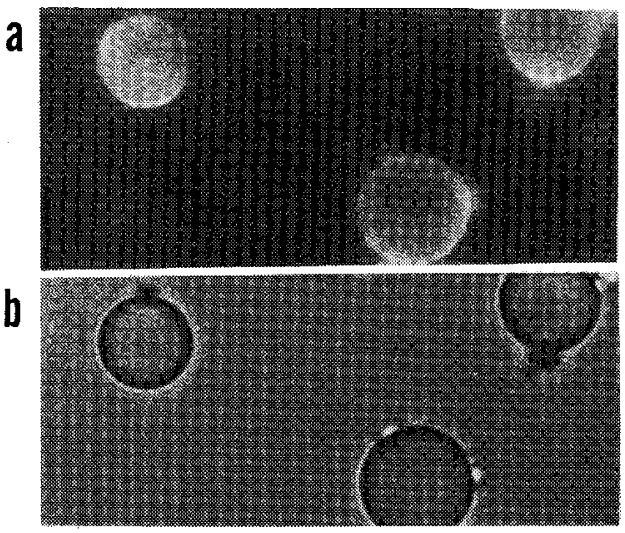

Fig. 1. Oil Droplets Stained for Surface $\alpha_{\mathrm{s} 1}$-Casein by Immunofluorescence (a).

Anti- $\alpha_{\mathrm{s} 1}$-casein antibody was incubated with the $\alpha_{\mathrm{s} 1}$ casein-stabilized emulsion and FITC-labeled anti-IgG was added to the emulsion. Observation of oil droplets by light microscope is shown in (b).

Table I. Absorption of Anti- $\alpha_{\mathrm{s}}$-Casein Antiserum With $\alpha_{\mathrm{s} 1}$-CASEIN Stabilized EMUlsion

Antiserum/Emulsion ratio $(\mathrm{V} / \mathrm{V})^{a}$

Amount of antibodies ${ }^{b}$

$\begin{array}{ll}\text { Control }^{c} & 1.263 \\ 1 / 50 & 0.020 \\ 1 / 10 & 0.181 \\ 1 / 1.33 & 0.434\end{array}$

a One milliliter of the emulsion was mixed with $20 \mu \mathrm{l}$ $(1 / 50), 100 \mu 1(1 / 10)$, or $750 \mu 1(1 / 1.33)$ of the antiserum to absorb the specific antibodies.

$b$ The amount of specific antibodies in the aqueous phase was measured by ELISA and expressed by absorbance at $405 \mathrm{~nm}$. The dilution ratio of the antiserum for this assay was $1 / 100(\mathrm{v} / \mathrm{v})$.

$c$ The antiserum was incubated in the absence of the emulsion. 


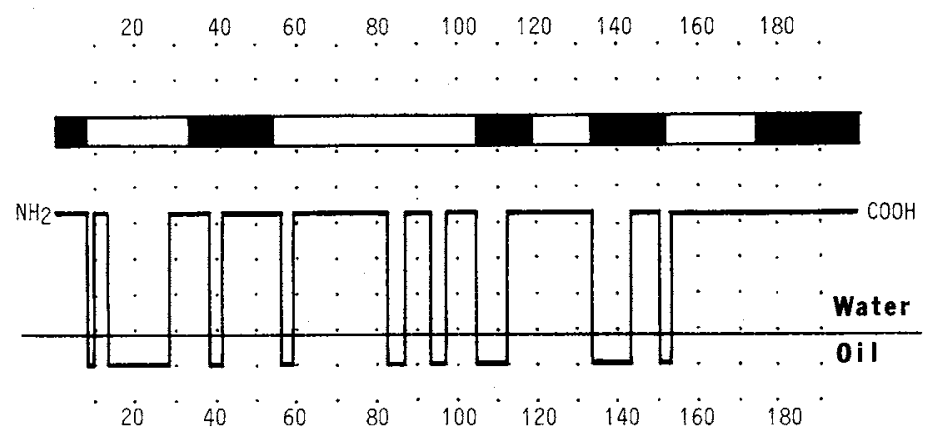

Fig. 2. Antigenic Portions of an $\alpha_{s 1}$-Casein Polypeptide Chain (Black Squares) and Schematic Representation of the $\alpha_{\mathrm{s} 1}$-Casein Chain Adsorbed to an Oil/Water Interface (ref. 2).

because no binding of the anti- $\beta$-lactoglobulin antibody to the $\alpha_{\mathrm{s} 1}$-casein-coated oil droplets was observed (data not shown). The anti- $\alpha_{s 1}-$ casein antibodies are considered to interact with the oil droplet surface through the specific antigen-antibody reaction.

The polyclonal anti- $\alpha_{s 1}$-casein antiserum was incubated with the $\alpha_{\mathrm{s} 1}$-casein-stabilized emulsion at different ratios, and antibodies which did not react with the $\alpha_{s 1}$-casein on the oil surface were recovered and measured by ELISA (Table I). When the emulsion/ antiserum ratio was small, a portion of the anti- $\alpha_{\mathrm{s} 1}$-casein antibody remained in the aqueous phase without being absorbed by the cream phase (oil droplets). When the antiserum was incubated with an excess of the emulsion, however, almost all of the antibody activity was lost in the aqueous phase. This indicates that all of the anti- $\alpha_{\mathrm{s} 1}$-casein antibodies present in the antiserum are reactive with $\alpha_{s 1}$-casein adsorbed onto the oil droplet surface. In other words, $\alpha_{\mathrm{s} 1}$-casein is adsorbed to the oil surface, all of its antigenic determinants being exposed to the aqueous phase.

We have already found that the antigenic determinants of $\alpha_{s 1}$-casein for $\mathrm{BALB} / c$ mice are localized in its four proteolytic fragments, the residues $33 \sim 54,105 \sim 119,133 \sim 151$, and $174 \sim 199 .{ }^{5)}$ Recently, a fragment, residues $1 \sim 8$, was observed to have another antigenic determinant site. ${ }^{6)}$ These portions of the $\alpha_{\mathrm{s} 1}$ casein molecule are, therefore, considered to be exposed to the aqueous phase of the emulsion. Location of these five regions is shown in Fig. 2, comparing with a model structure of an $\alpha_{\mathrm{s} 1}$-casein chain adsorbed to an oil/water interface, which we have proposed in our previous paper. ${ }^{2)}$

In our previous model, the $\mathrm{N}$-terminal and C-terminal portions of $\alpha_{\mathrm{s} 1}$-casein were thought to be located in the aqueous phase, not being involved in the interaction with the oil phase. This was confirmed by this study. With regard to the other three portions residues $33 \sim 54$, $105 \sim 119$, and 133 151, the previous model implied that each portion contained one oil binding-site, ${ }^{2)}$ although they are thought to have antigenic determinant sites being extended to the aqueous phase in this study. This is, however, not contradictory because the size of an antigenic determinant of proteins is considered to be around 6 amino acid residues. ${ }^{7)}$ The fragments, residues 33 54, 105 119, and $133 \sim 151$, would be big enough to contain both an oil-binding site and an antigenic determinant site which is exposed to the aqueous phase.

In conclusion, the present immunological approach suggested that the five antigenic determinants in $\alpha_{\mathrm{s} 1}$-casein are all located on the outer surface of the $\alpha_{\mathrm{s} 1}$-casein film surrounding the emulsified oil droplets. They are exposed to the aqueous phase and reactive with the antibodies present in the aqueous phase. These findings do not contradict the structure model of $\alpha_{s 1}$-casein at an oil/water 
interface which we have proposed in our previous paper. ${ }^{2)}$

\section{References}

1) J. R. Mitchell, "Developments in Food Proteins-4," ed. by B. J. F. Hudson, Elsevier Appl. Sci. Pub. Ltd., New York, 1986, p. 291.

2) M. Shimizu, A. Ametani, S. Kaminogawa and $\mathbf{K}$. Yamauchi, Biochim. Biophys. Acta, 869, 259 (1986).
3) Z. Hollander and E. Katchalski-Katzir, Mol. Immunol., 23, 927 (1986).

4) S. A. Darst, C. R. Robertson and J. A. Berzofsky, Biophys. J., 53, 533 (1988).

5) A. Ametani, S. Kaminogawa, M. Shimizu and $K$. Yamauchi, J. Biochem., 102, 421 (1987).

6) A. Ametani, S. M. Kim, S. Kaminogawa and K. Yamauchi, Biochem. Biophys. Res. Commun., 154, 876 (1988).

7) M. Z. Attasi, Eur. J. Biochem., 145, 1 (1984). 